\title{
Recent developments in nucleic acid based techniques for use in rumen manipulation
}

\author{
Christopher McSweeney', Seungha Kang ${ }^{1}$, Emma Gagen ${ }^{1}$, Carl Davis ${ }^{1}$, Mark Morrison ${ }^{1}$, \\ Stuart Denman ${ }^{1}$
}

${ }^{1}$ CSIRO Livestock Industries, Queensland Bioscience Precinct, St Lucia, QId, 4067, Australia.

\begin{abstract}
Nucleic acid-based techniques which can be used to characterise complex microbial communities without incubation are now being employed regularly in ruminant nutrition studies. Conventional culture-based methods for enumerating rumen microorganisms (bacteria, archaea, protozoa, and fungi) have been superseded and are now used mainly to obtain pure isolates of novel organisms and reference strains that are required for the development and validation of the nucleic acid approaches. These reference strains are also essential for physiological studies of the lifestyle of the organisms as well as sources of genomic DNA and RNA that can be analysed for functional gene activity. The foundation of the molecular ecology techniques is $16 \mathrm{~S} / 18 \mathrm{~S}$ rDNA sequence analysis which has provided a phylogenetically based classification scheme for enumeration and identification of microbial community members. The use of this marker gene in assays involving the use of single nucleic acid probes or primer sets is rapidly evolving to high throughput approaches such as microarray analysis and new generation sequencing technologies. While these analyses are very informative for determining the composition of the microbial community and monitoring changes in population size, they can only infer function based on these observations. The focus of nucleic acid research is now shifting to the functional analysis of the ecosystem which involves the measurement of functional genes and their expression in the predominant or specific members of the rumen microbial community. Functional gene studies are less developed than 16S rDNA-based analysis of community structure. Also for gene expression studies there are inherent problems involved in extracting high quality RNA from digesta, and priming cDNA synthesis from bacterial mRNA. This paper reviews nucleic acid based molecular methods which have recently been developed for studying the structure and function of rumen microbial communities.
\end{abstract}

Key Words: ecology, functional analysis, microbial, molecular, ribosomal, rumen

\section{Recent developments in nucleic acid based techniques for use in rumen manipulation}

RESUMO - Metodologias baseadas na análise de ácidos nucléicos, que possam ser utilizadas para caracterizar comunidades microbianas complexas, sem a necessidade da incubação de amostras, têm sido empregadas atualmente, de forma rotineira, em estudos de nutrição de ruminantes. Os métodos convencionais, dependentes do cultivo microrganismos ruminais (bactérias, archaea, protozoarios e fungos) para sua enumeração foram superados e atualmente passaram a ser utilizados especialmente para o isolamento de cepas puras de organismos ainda desconhecidos e para o cultivo de cepas de referência, necessários para o desenvolvimento e a validação das metodologias de análise de ácidos nucléicos. Tais cepas de referência são também essenciais para estudos fisiológicos e ainda, funcionam como fontes de DNA e RNA para avaliação da expressão gênica. O fundamento das metodologias de ecologia molecular é a análise de sequências de 16S / 18S rDNA, que fornece um esquema de classificação de base filogenética, utilizado para a enumeração e identificação de membros de uma comunidade microbiana. O uso de marcadores de genes e estudos envolvendo o uso de sondas individuais de ácidos nucléicos ou de conjuntos de primers tem evoluído rapidamente para abordagens de alto desempenho ("high throughput"), como por exemplo analises de microsatélites e novas metodologias para sequenciamento. Entretanto, se por um lado tais métodos são muito úteis para a determinação da composição da microbiota e para o monitoramento de variações nos tamanhos das populações componentes, por outro lado, os mesmos apenas auxiliam na inferência das funções em relação à composição ou ao tamanho de determinada população. Portanto, o foco de pesquisas baseadas em metodologia de ácidos nucléicos esta mudando para a analise funcional de um ecossistema, o quê envolve a mensuração de genes funcionais e sua expressão nos membros predominantes ou, membros específicos da microbiota ruminal. Estudos da expressão gênica ainda são menos desenvolvidos do que aqueles de analise da microbiota baseada no rDNA. Além disso, existem problemas intrínsecos aos estudos de expressão gênica relacionados à extração de RNA de alta qualidade a partir da digesta, e também em relação ao processo da iniciação da síntese de cDNA a partir de mRNA bacteriano. Este artigo oferece uma revisão dos métodos moleculares baseados em ácidos nucléicos que foram desenvolvidos recentemente para estudos de estrutura e função da microbiota ruminal.

Palavras-chave: análise funcional, ecologia microbiana, molecular, ribosomal, rúmen 


\section{Introduction}

During the $20^{\text {th }}$ century, the study of rumen microbiology was primarily based on classical culturebased techniques, such as isolation, enumeration and nutritional characterization, which probably only account for 10 to $20 \%$ of the rumen microbial population. These traditional methods are time consuming and cumbersome, but have identified more than 200 species of bacteria and at least 100 species of protozoa and fungi inhabiting the rumen (Orpin \& Joblin 1997; Stewart et al., 1998; Williams \& Coleman 1998; White et al., 1999). New nucleic acid-based technologies can now be employed to examine microbial community structure primarily through the use of small subunit (SSU) rRNA gene analysis (eg 16S and 18S rRNA) and to understand the function of complex microbial ecosystems through the combined analysis of multiple genomes (metagenomics) and the message from the expressed genes (mRNA) in the rumen. Several recent reviews and technical manuals have been written on the subject of molecular microbial ecology of animals which provide a broad perspective of the variety of techniques available and their potential application in the field of animal science which is beyond the scope of this paper (see Zoetendal et al., 2003, Zoetendal et al.,2004, Zoetendal et al., 2008; Makkar \& McSweeney, 2005; McSweeney et al., 2006; Mackie et al.2007). These publications provide a perspective on how to design animal trials in which microbial ecology is studied. Often the power of the new molecular techniques is diminished by an inappropriate design in terms of animal number, sampling frequency, location and replication. The classical culture-based methods for studying rumen microbes are described since a laboratory that intends using molecular microbial ecology techniques for studying the rumen must have a capacity to grow and isolate microorganisms under anaerobic conditions. There is information on the basic underpinning techniques and protocols in molecular ecology such as DNA extraction from environmental samples, the quantitative real-time polymerase chain reaction ( $\mathrm{qPCR}$ ), oligonucleotide probe and primer design, and DNA fingerprinting amongst others, as well as the application of these techniques to microbial detection and identification are discussed. Specialised techniques such as denaturing gradient gel electrophoresis (DGGE) and 16S/18S ribosomal DNA libraries for studying complex communities that contain unculturable organisms are also compared. Many of these techniques are used to identify and enumerate the populations of organisms that are present in a sample. Techniques such as fluorescent insitu hybridization (FISH) which uses 16S rRNA-targeted oligonucleotide probes combined with epifluorescent light microscopy or confocal laser microscopy provide knowledge about location and spatial relationships of microorganisms in their natural environment that are often essential to understanding the function of these organisms. This paper will focus on DNA/RNA based molecular methods which have recently been developed for studying complex microbial communities that are important in nutritional studies, as well as, novel methods for studying microbial diversity and function from a genomics perspective. Metagenomic technologies, which provide the potential to capture and study the entire microbiome (the predominant genomes) from a complex microbial community in the rumen are described. Also rapid high-throughput technologies such as microarray analysis as well as next generation sequencing technologies developed in mapping the human genome are now being deployed to study microbial ecosystems. An explosion of knowledge in the field of microbial ecology is therefore predicted. However the field is rapidly moving to a functional analysis of the microbes in the ecosystem and some of the methods being employed to measure genes expression of the entire gut microbiome are also described.

Recent developments in molecular methods which target the rRNA gene operon and related transcripts

Several techniques involving PCR based amplification of regions within the rRNA gene operon have been developed specifically for analysis of the diversity and abundance of microorganisms in the rumen including the protozoa, fungi, bacteria and methanogens. These methods have been recently described and their application reviewed comprehensively (McSweeny et al. 2006, Mackie et al., 2007). However since these reviews there have been further developments in some of the techniques which enhance the ease of analysis and enable more samples to be analysed in a cost effective manner. In addition efficient extraction protocols for the recovery of RNA from gut samples have been developed. Also new primer sets have been published for detection of a greater range of rumen microorganisms. This new information and how it pertains to the predominant microbial populations in the rumen are provided below.

\section{$r R N A$ recovery and analysis}

Molecular methodologies relying on 16S rRNA gene sequences are now commonly used for the identification and classification of bacterial species within mixed microbial populations (Salzman et al., 2002; Edwards et al., 2004). In general, DNA from rumen digesta is used as template for PCR amplification of bacterial 16S rRNA genes and 
subsequent community analysis (Larue et al., 2005; Yu \& Morrison, 2004a, Yu \& Morrison, 2004 b, Yu et al., 2008). However, microbial community structure inferred from genomic DNA-based analysis does not take into account the viability or metabolic state of community members (Sessitsch et al., 2002). RNA-based community analysis is more suitable to describe the metabolically active members of a population, as the amount of rRNA produced by cells is directly correlated with the growth activity of bacteria (Wagner et al., 1994). Only a few papers have reported the analysis of active gut bacteria by using rRNA as template for temperature gradient gel electrophoresis (Sokol et al., 2006, Zoetendal et al., 1998). Most of the previous studies on microbial diversity have used DNA based methods because (1) RNA is prone to degradation and thus extraction of high quality RNA from environmental samples is more difficult than DNA extraction, and (2) phenolic compounds and other inhibitors in gut samples can be co-extracted and interfere with subsequent synthesis of complementary DNA (cDNA). Various methods have been reported for the recovery of RNA from environmental samples but in the rumen a large proportion of the bacteria are strongly attached to particles of digesta and need to be dissociated prior to RNA extraction. A new extraction protocol for recovering RNA from microbial communities in the rumen has been developed which involves a dissociation step followed by enzymatic lysis and bead beating of cells in the presence of an RNA preservative (Kang et al., 2009). When this rRNA based approach was used to examine microbial diversity in the rumen it was found that about $30 \%$ of the randomly sequenced $16 \mathrm{~S}$ rRNA amplicons were related to the Proteobacteria providing the first evidence that this group may have greater importance in rumen metabolism than previously attributed by DNA-based analysis which typically records much lower levels of Proteobacteria.

\section{Rumen protozoa and anaerobic fung $i$}

Several molecular techniques including qPCR and DGGE have been developed to monitor the abundance and diversity of different genera and species of rumen protozoa which have been comprehensively reviewed previously (McSweeney et al., 2006). A rapid and specific qPCR technique has been developed to quantify the abundance of anaerobic rumen fungi (ARF) but recently this method has been improved by the design of new primers which show greater coverage of the rumen fungal population (Denman \& McSweeney, 2008; Edwards et al., 2008). However this method does not discriminate between the different fungal genera which is required for diversity analysis To address this issue of community analysis, an automated ribosomal intergenic spacer region (ARISA) method for the detection and monitoring of anaerobic rumen fungi has been developed (Denman \& McSweeney, 2008; Edwards et al., 2008). Use of 18s rRNA sequences for comparing rumen fungi is of limited use due to the highly conserved nature of $18 \mathrm{~s}$ rRNA sequences in these organisms (97-100\% sequence identity) (Doré \& Stahl 1991). As an alternative, the internal transcribed spacer region 1 (ITS1) of the rRNA genes has been used for studying genetic diversity. The presence of a length polymorphic region within the ITS 1 region of gut fungi ranging from $\sim 220$ bp for Orpinomyces sp. and up to $\sim 290$ bp forNeocallimastix spp. was first exploited by Nicholson et al. (2002). PCR amplification of the length polymorphic region using anaerobic fungal specific primers, followed by separation of the PCR products on high-resolution gels was shown to be a useful tool for quickly identifying fungal members from faecal samples. As members of the same genera tended to have a similar length polymorphic region, it was possible to discriminate fungal genera based on gel mobilities in high-resolution gels. This method was further developed through the labelling of the forward primer with carboxyfluorescein (FAM) and then separation of the products using a genetic sequence analyzer thus identifying gut fungi populations from cattle rumensamples. The ARISA technique is capable of clearly discriminating to the genus level between pure cultures. Using this method, significant changes in the composition of the ARF population were observed between animals fed a high fibre diet compared to those animals being fed a diet high in grain. The technique has also been used to study the dynamics of initial colonization of forage by anaerobic fungi (Edwards et al., 2008). Through the use of ARISA monitoring, it is possible therefore to obtain a better understanding of the temporal interrelationships between diets and the different members of ARF community.

\section{Rumen bacteria}

Most of the research which has employed molecular analysis of rumen bacteria has centered on the role of the three predominant fibre degrading bacteria Fibrobacter succinogenes, Ruminococcus albus and Ruminococcus flavefaciens. Several studies have published different sets of PCR primers that have been designed to amplify each of these bacterial populations. The use of some of these primer sets and the relative advantages of each have been evaluated and discussed by Mosoni et al. (2007). It appears that primer design for these bacteria has been adequately developed and can be employed with confidence in the quantitative nature and specificity of the results. 
Primer pairs have now been published for detection of other rumen bacteria (Anaerovibrio lipolytica,Butyrivibrio fibrisolvens, Eubacterium ruminantium, Prevotella albensis, P. brevis, P. bryantii, P. ruminicola, Ruminobacter amylophilus, Selenomonas ruminantium, Streptococcus bovis, Succinivibrio dextrinisolvens, Treponema bryantii, Genus Prevotella) using qPCR assays (Stevenson \& Weimer 2007; Tajima et al., 2001; Weimer et al., 2008). Specific primers forMegasphaera elsdenii have also been developed for studies on rumen acidosis (Ouwerkerk et al., 2002).

\section{Rumen methanogens}

The molecular methods used to measure diversity and abundance of rumen methanogens are well advanced and have been described previously (McSweeney et al., 2006). Since then an excellent review of the literature has provided an overview of the structure of the archael community structure in the rumen (Janssen \& Kirs, 2008). Based on this meta-analysis, the majority of rumen archaea affiliate with three genus-level groups; Methanobrevibacter, Methanomicrobiumand a large group of uncultured rumen archaea whose nearest relatives are the thermophilic Thermoplasma sp. These conclusions about the general structure of the rumen archael community are also consistent with the most recent publications on diversity of methanogens from domesticated ruminants in the northern and southern hemisphere (Wright et al., 2007; Wright et al., 2008).

Currently the most reliable method for estimating the abundance of rumen methanogens is the qPCR technique that targets the methyl coenzyme-M reductase ( $m c r A$ gene) which is ubiquitous to methanogens and is crucial to the terminal step of methanogenesis (Denman et al., 2007). An accurate qPCR technique which tagets the 16S rDNA gene and is specific for the rumen methanogens is not yet available. Analysis of rumen methanogen diversity has previously relied mainly on 16S rRNA gene clone libraries but these methods are restrictive when analyzing multiple samples in response to dietary treatments over time. A technique based on PCR amplification of the 16S rRNA gene with archael specific primers and profiling of the banding pattern of the amplicons using DGGE has been recently published (Yu et al., 2008).

\section{High throughput phylogenetic analysis}

Nucleic acid based microarrays have recently been employed for the high throughput analysis of complex microbial ecosystems. This technology is likely to be enhanced by future developments in DNA sequencing technology and bioinformantic analysis so that the breadth and depth of the analysis of the ecosystem will be extended by linking community structure with function. The two main types of microarray in current use are phylogenetic oligonucleotide microarrays with short nucleic acid probes (20-50 bases) and functional gene arrays containing probes targeting genes encoding specific functions. In this review, important methodological developments relevant to the application of the different types of diagnostic microarrays in rumen ecology will be addressed and new approaches, needs and future directions will be identified.

Recently, Palmer et al. (2006) developed a DNA oligonucleotide microarray composed of 10,462 small subunit (SSU) ribosomal DNA (rDNA) probes ( 7167 unique sequences) selected to provide quantitative information on the taxonomic composition of diverse microbial populations. They were able to identify and quantitate members of the microbial community however many of the probes were designed for diverse taxonomic groups and only a few were species specific. To increase efficiency of target bacterial specificities on the microarray, we employed a new probe design program, GoArray (Rimours et al., 2005) which could combine excellent specificity with higher sensitivity. Therefore, we designed a phylogenetic custom microarray with 40 base length nucleotide probes which targeted the hyper-variable region of $16 \mathrm{~S}$ rDNA gene. The microarray was composed of probes already designed in published papers (Palmer et al., 2006; Wang et al., 2004 ) and probes newly designed with the GoArray program.

In a recent experiment we compared total rumen microbial diversity based on genomic and RNA based analysis of the 16 rRNA gene and transcripts to determine whether our understanding of population structure in the rumen was influenced by the target material chosen. Bacterial DNA and RNA from cattle rumen was extracted and amplified using bacterial primers with the modification of a $\mathrm{T} 7$ promoter sequence attached to the reverse primer (27F - 1492_T7R) followed by cRNA synthesis and labelling with Cy5. Microbial diversity and abundance were observed by hybridization to a $16 \mathrm{~S}$ rDNA based custom microarray. Phylogenetic libraries were generated from rRNA and compared with previously generated rDNA based phylogenetic data. Within the rumen microbial community the Proteobacteriagroup has been reported to be less than $2 \%$ of total bacterial population based on rDNA analysis. RNA based analysis showed that Proteobacteria represented $28 \%$ of the clones sequenced from the $16 \mathrm{~S}$ rDNA library. Similarly, RNA based microarray data showed Proteobacteria to be 8 times higher compared to DNA samples. The results suggest that the Proteobacteria group 
may make a greater contribution to rumen metabolism than previously recognized but the functions of this group in the rumen require further investigation.

\section{Nucleic acid based analysis of rumen function}

Over the last decade, molecular ecology studies of the rumen microbiota have focused almost entirely on identifying and enumerating populations. While these analyses are very informative for determining the composition of the microbial community and monitoring changes in population size, they can only infer function based on these observations. The next major step in understanding rumen function is to link structural analysis of the microbial community with measurements of functional gene activity. This genetic activity (mRNA) is translated into protein and metabolic functions which ultimately characterize the ecosystem at any particular time. For example the relative abundance and enzymatic activity of a discrete functional group of rumen bacteria (eg cellulolytics) will vary depending on diet and time in relation to feeding cycle. In this regard it is often better to focus on a key metabolic activity within the ecosystem (eg methanogenesis, protein metabolism, cellulolysis etc) and apply the required molecular tools to define the relevant microbial populations and associated enzymatic activities. The challenge is to understand and describe the biology at a molecular level so that feeding systems can be tailored for maximum efficiency of digestion in the rumen.

\section{Metagenomics}

A DNA-based approach which has gained rapid adoption as a way of studying community function is metagenomic analysis. Metagenomics is defined as the study of collected genomes from an ecosystem that can be used to examine the phylogenetic, physical and functional properties of microbial communities (Handelsman, 2004). The principle steps in this form of analysis is the extraction of DNA from the microbial community followed by cloning of the DNA fragments in a suitable host (eg E. coli) using a fosmid or bacterial artificial chromosome vector which results in a library of many thousands of clones. The clone library can then be screened using specific DNA sequences in a PCR or hybridization based approach for genes encoding discrete steps in known metabolic pathways or enzymatic activities. Also activity-driven assays can be performed to screen the library for novel enzymes or specific activities and function. The advantage of this approach is that the activity assay may identify clones with novel gene sequences encoding for functions which would have been missed by DNA screening, based on current sequence information in the database. Clones identified in either screening strategy are then subjected to a variety of sequencing technologies and computational analyses which enables the assembly and annotation of large inserts $(>40 \mathrm{~kb})$ of genomic DNA from the clones. Ultimately metagenomic analysis creates a catalogue of genomic information which can be interrogated to gain insights into the predominant genes, how they are regulated and their contribution to ecosystem function. Functional gene analysis and annotation is undertaken by using a pipeline process to transform the DNA-sequence data via translation to amino acid sequence, similarity searches and annotation using public databases and functional data. For example, the DNA sequence data of the inserts can be binned (grouped on similarity and frequency of occurrence) and annotated using various gene identification and database tools (eg ContigExpress, Phylopythia, MEGAN and MG-Rast), to classify the genes within known enzyme families or clusters of orthologous genes (COGs) and metabolic pathways. By using this process, a catalogue of the genetic capacity of the ecosystem can be determined as well as providing an avenue to identify novel genes or genes of unknown function from the environment. This approach has been employed to screen rumen-DNA metagenomic libraries for enzymes involved in depolymerisation of lignocellulose and starch with the discovery of a range of novel enzymes including laccases (Beloqui et al., 2006; Ferrer et al., 2005; Ferrer et al., 2007). A bacterial artificial chromosome library has also been constructed from the rumen of a dairy cow and is being used to screen for novelenzyme activities (Zhu et al., 2007).

\section{Gene expression analysis}

Another way of describing the activity of functionally discrete microbial groupsin vivo is to measure the expression of genes that define the function. Currently there are few published studies of gene expression in rumen microorganisms under eitherin-vitro or in-vivoconditions (Bera-Maillet et al., 2004; Krause et al., 2005; Guo et al., 2008). Gene expression can be sensitively analyzed by amplification of messenger RNA (mRNA) using reverse transcription-PCR (RT-PCR) to produce cDNA as template for further analysis. Gene expression studies are less developed than DNA-based analysis of community structure due to the inherent problems involved in extracting high quality RNA from digesta, and priming cDNA synthesis from bacterial mRNA that lacks a polyadenylated tail. RTPCR requires the activities of reverse transcriptase (RTase) in making the cDNA from the template mRNA.

In some cases the identity of important functional genes is already known and direct measurement of the 
expression of these genes can be used to monitor ecosystemfunction. A detailed description of the techniques involved in performing gene expression analysis for ruminant applications are described by Yu \& Forster (2005). These techniques can be applied to studies of single genes or many genes in samples from pure cultures or complex microbial communities. The abundance of particular mRNA can be quantified by real-time RT-PCR or by using DNA microarrays. Quantitative real-time RT-PCR for gene expression analysis is similar in principle to real-time PCR for enumeration of microbial populations once cDNA template is synthesised from mRNA transcript (Yu \& Forster, 2005; Guo et al., 2008). However these quantitative techniques for measuring expression of single genes are limiting when the objective of the study is to use gene expression analysis to understand the lifestyle of a single organism or main functions within an ecosystem. In this case DNA-based microarrays has been used successfully for studying the genome function of a single organism and these techniques have now been applied to complex microbial ecosystems (Dennis et al., 2003). The foundation for developing an expression array for a single organism is the sequence information generated from the whole genome of the target organism which is used to design probes for the different open reading frames (ORFs) that have been identified. To date, only a few studies using expression array profiling have been reported for rumen microorganisms and primarily for investigating the genes involved in polysaccharide degradation by cellulolytic bacteria (Krause et al., 2003; Qi et al., 2005).

\section{Next generation sequencing technology}

Until recently the limitation of many of the current methods in molecular microbial ecology was that they were dependant upon DNA sequence information from isolated microorganisms or from 16S rDNA clone libraries which had been generated by expensive and slow sequencing technologies. New-generation DNA sequencing technologies (eg pyrosequencing) are now available which provide high throughput capacity and continuous sequence reads from 250-500bp in a cost-effective manner (Margulies et al., 2005). To further increase cost savings with phylogenetic based studies, researchers can take advantage of "barcoding" individual samples by incorporating several unique base pair tags into the PCR primers for each sample then pooling all samples prior to sequencing. This allows for greater statistical power in experimental design and data interpretation, where previously researches have often pooled individual samples prior to sequencing.
Next generation sequencing allows for the metagenomic analysis of complex microbiomes and therefore delivers more information than just phylogenetic descriptions of the system. Although at this stage due to the small read lengths complex communities are difficult to assemble into large sequence contigs and therefore assigning functional roles of individual bacteria within a metagenome is not yet possible (Kunin et al., 2008). However next generation sequencing technology has been recently employed in the metagenomic analysis of the specific glycoside hydrolases (fibre-degrading enzymes) that are associated with the fiber-adherent bovine rumen microbiome (Brulc et al., 2009).

Use of DNA based techniques to study community structure and function involving alternative hydrogen sinks to methanogenesis

Our current understanding of the microbial processes underpinning hydrogen utilization and methane production within the rumen is incomplete and the key to manipulating these emissions in the future will flow from fundamental improvements in our knowledge of methanogenesis and alternative hydrogenotrophic pathways. Reductive acetogenesis is an alternative hydrogen-utilising pathway to methanogenesis in the rumen and has potential as a strategy for reducing ruminant greenhouse gas emissions. The obligately anaerobic bacteria responsible for reductive acetogenesis are known as homoacetogens. Homoacetogens use the acetyl-CoA pathway to reduce carbon dioxide to acetate, and most are able to use this pathway for growth on hydrogen and carbon dioxide as the sole energy source (Drake, 1994).

Homoacetogens are present in the rumen and appear to cover a broad taxonomic group but they are poorly represented in culture collections and thus molecular tools are necessary to further investigate their ecology (Joblin, 1999). However it is difficult to infer function to phylotypes when the acetogenic phenotype is presents in diverse taxanomic groups. Therefore in the current work we have attempted to identify DNA sequences of genes present in homoacetogens that may be suitable as targets for the development of functional-group molecular tools for these microorganisms.

\section{Functional genes specific for hydrogenotrophic pathways}

Libraries were created for several functional genes to enable the design of specific probes and realtime PCR primer sets for key genes involved in hydrogenotrophy. These libraries were established using DNA recovered from hydrogenotrophic batch fermentations using degenerate 
primer sets to ensure maximal coverage of target sequences. The genes investigated were those of three key enzymes in the acetyl-CoA pathway (Figure 1): formyltetrahydrofolate synthetase (FTHFS), carbon monoxide dehydrogenase $(\mathrm{CODH})$ and acetyl-CoA synthase (ACS). Previously validated PCR primer sets have been designed for the amplification of the FTHFS gene (Leaphart \& Lovell, 2001) but there is little information available for the $\mathrm{CODH}$ and ACS sequences that would enable the design of primers specific for these genes. CODH, ACS amino acid sequences were retrieved from public databases (Brenda and NCBI via BLAST analysis) and aligned. The only sequences from an authentic homoacetogen were from Moorella thermoacetica. All other sequences were from genomes of a variety of archaea and bacteria, none reported to be homoacetogenic. Newly developed degenerate PCR primers were designed across conserved amino acid regions for $\mathrm{CODH}$ and ACS.

Hydrogenotrophic batch fermentation systems inoculated with rumen microbes from either pasture or grain fed animals were established using ${ }^{13} \mathrm{C}$-Sodium carbonate as the principal carbon and energy source, and in the presence or absence of bromoethanesulfonate (BES) to inhibit methanogenesis. VFA and gas analyses were performed to characterize and monitor fermentative changes, hydrogen and carbon balances. Metagenomic DNA was extracted and isotope ratio mass spectrometry (IRMS) was used to confirm the uptake of ${ }^{13} \mathrm{C}$ into the DNA, followed by the separation of ${ }^{13} \mathrm{C}$-labeled DNA via isopycnic gradient ultracentrifugation. The ${ }^{13} \mathrm{C}$-labeled DNA was used as a template for the production of $16 \mathrm{~S}$ rDNA phylogenetic and FTHFS, CODH and ACS clone libraries, as well as metagenomic (fosmid) libraries and 454 short read sequencing. Putative FTHFS, CODH and ACS sequences were also generated from DNA of known homoacetogens: M. thermoacetica, Clostridum aceticum, Acetobacterium woodii, Ruminococcus hydrogenotrophicus, and Eubacterium limosum.

The majority of FTHFS sequences obtained from the batch fermentations grouped within the homoacetogenic cluster dominated by clostridial representatives (Leaphart et al., 2003). There was a high degree of similarity between the pasture fed and grain fed enrichments, although the pasture fed enrichments also were highly represented by a group that clustered close to Proteus vulgaris, a nonacetogenic bacterium (Figure 2). Putative CODH and ACS sequences were also generated from DNA obtained from rumen enrichment cultures of homoacetogens, from the rumen of cattle. Clusters of sequences for both these genes aligned close to Ruminococcus obeumfor both functional genes and similar results were obtained from the 454 sequencing analysis. The analysis revealed limited diversity of these functional genes with respect to pasture or grain based diets.

In summary, an extensive set of primers have been developed from the numerous phylogenetic and functional gene databases. These primers and probes are being used to target key enzymatic steps in hydrogen sequestering

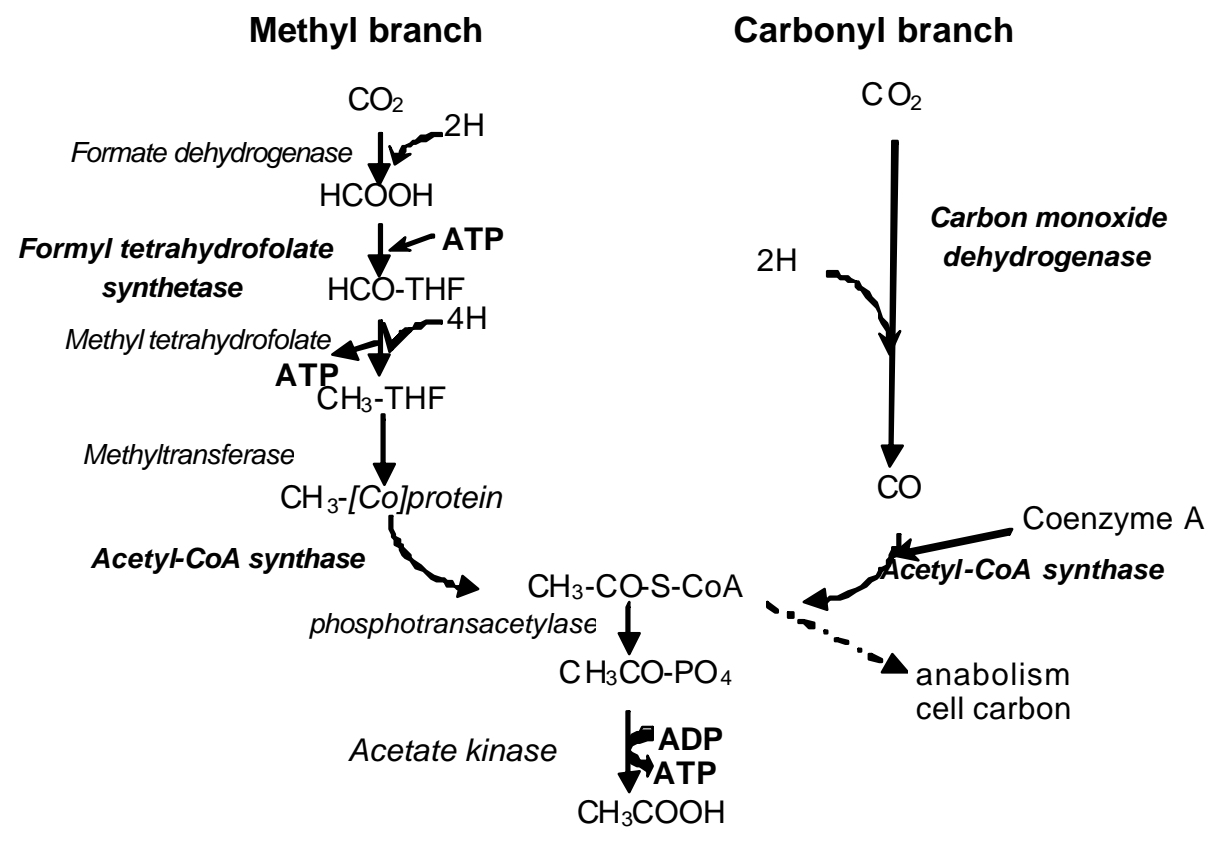

Figure 1 - The reductive acetogenesis pathway. Adapted from Drake (1994). 
pathways for use in probing the metagenomic fosmid libraries and monitoring populations of hydrogen-utilising microorganisms in the rumen.

Molecular characterization of fluoroacetate degrading rumen bacteria

Monofluoroacetate (FA) is a highly toxic compound, found in over 40 species of plants around the world and is responsible for poisoning thousands of livestock (McCosker, 1989). Microbial degradation of FA is known to occur in numerous aerobic bacteria and is catalysed by fluoroacetate dehalogenase (Kawasaki et al., 1981) however its fate within anaerobic environments is still unknown. The use of fluoroacetate dehalogenase gene has been applied to the development of a transgenic rumen organism which detoxifies fluoroacetate within the gastrointestinal tract of livestock (Gregg et al., 1994; Gregg et al., 1998; Padmanabha et al., 2004). Concerns over the release of this genetically modified organism has prompted us to search for natural microorganisms that may be better suited to the purpose. Despite the interest in the microbial degradation of FA, there are a surprisingly small number of reports where this halogenated aliphatic compound is degraded under anaerobic conditions (Kim et al., 2000).

We were able to enrich and isolate a bacterium from the cattle rumen which rapidly degrades FA. The $16 \mathrm{~S}$ rRNA gene sequence of the isolate was $95 \%$ similar to that of Cloacimonas acidaminovorans which belongs to the phylum Synergistes. The closest known rumen relative to the fluoroacetate degrading isolate is Synergistes jonesii (also known as the 'leucaena bug') which is able to detoxify the plant toxin dihydroxypyridine. The FA degrading bacterium uses amino acids for energy and growth which is a characteristic of all members of the Synergistes division. In the presence of FA, significantly more amino acids are utilized and growth is enhanced. Studies of the oxidation-

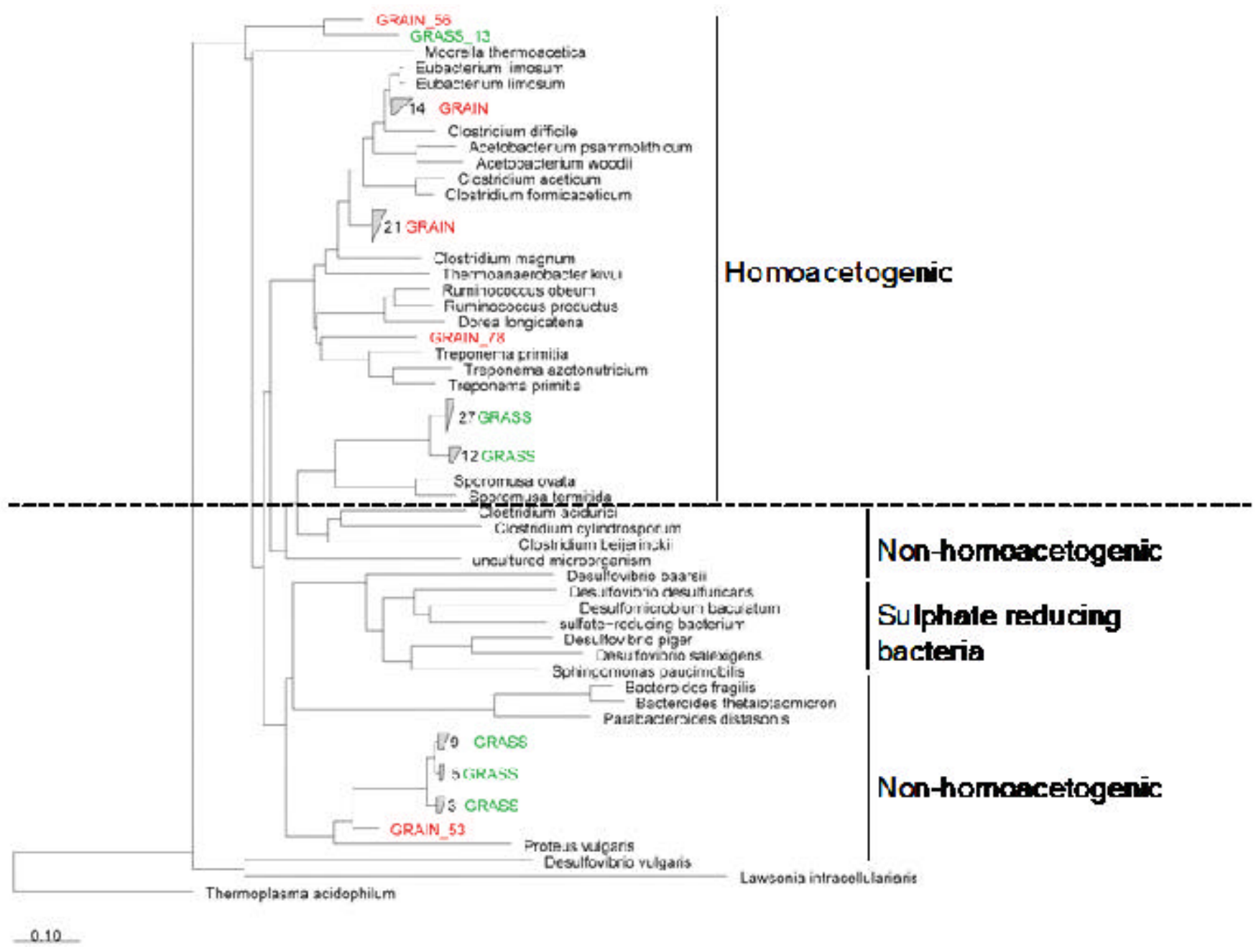

Figure 2 - FTHFS sequences retrieved from enrichment cultures of rumen fluid sourced from cattle fed either grass or grain based diets. 
reduction reactions associated with the utilization of FA indicate that the organism is likely to derive energy through the metabolic process called halorespiration. We believe this is the first report of reductive dehalogenation involving a fluorinated compound. The genome of Cloacimonas acidaminovoranshas been sequenced and annotated thus providing a reference for the sequence analysis of Synergistes jonesii and the deflourinating bacterium which is currently underway in our laboratory. Mining the genes of these unique rumen bacteria should provide insights into their nutritional and physiological requirements which can be exploited in management programs to optimize their detoxifying capacity in the rumen.

\section{Conclusions}

Recent developments in DNA-based technology which employ high throughput approaches will enable the (meta)genomic analysis of individual bacteria and rumen samples from multiple animals to be processed rapidly and in a cost effective manner. This will ensure that the structure and function of complex microbial communities as well as detailed analysis of important sets of organisms can be achieved. These technologies have the potential to revolutionize the understanding of rumen fermentation. However, a better knowledge of microbial function and ecology will need to be integrated with nutritional principles if ruminant production is to benefit.

\section{Literature Cited}

BELOQUI, A.; PITA, M.; POLAINA, J. et al. Novel polyphenol oxidase mined from a metagenome expression library of bovine rumen: biochemical properties, structural analysis, and phylogenetic relationships. Journal of Biological Chemistry, v.281, p.22933-22942, 2006.

BERA-MAILLET, C.A.; KWASIBORSKI, P.; MOSONI, E. et al. Quantification of Fibrobacter succinogenes cellulase and xylanase gene expression in the rumen of a gnotobiotic lamb by real-time RT-PCR. INRA-RRI 2004 Gut Microbiology 4th Joint Symposium, Clermont-Ferrand, France. Reproduction Nutrition and Development, v.44 (Suppl. 1), p.S57, 2004.

BRULCA, J.M.; DIONYSIOS, A.; ANTONOPOULOSB, M.E. et al. Gene-centric metagenomics of the fiber-adherent bovine rumen microbiome reveals forage specific glycoside hydrolases. Proceedings of the National Academy of Science United States of America, v.106, p.1948-1953, 2009.

DENNIS, P.; EDWARDS, E.A.; LISS, S.N. et al. Monitoring gene expression in mixed microbial communities by using DNA microarrays. Applied and Environmental Microbiology, v.69, p.769-778, 2003.

DENMAN, S.E.; MCSWEENEY, C.S. Development of a real-time PCR assay for monitoring anaerobic fungal and cellulolytic populations within the rumen. FEMS Microbial Ecology, v.58, p.572-582, 2006.

DENMAN, S.E.; NICHOLSON, M.J.; BROOKMAN, J.L. et al. An ARISA method for detecting anaerobic rumen fungi diversity.
Letters in Applied Microbiology, v.47, 492-499, 2008.

DENMAN, S.E.; TOMKINS, N.; MCSWEENEY, C.S. Quantitation and diversity analysis of ruminal methanogenic populations in response to the anti-methanogenic compound bromochloromethane. FEMS Microbial Ecology, v.62, p. 313-322, 2007.

DORE, J.; STAHL, D.A. Phylogeny of anaerobic rumen chytridiomycetes inferred from small subunit ribosomal-RNA sequence comparisons. Canadian Journal of Botany, v.69, p.1964-1971, 1991.

EDWARDS, J.E.; McEWAN, N.R.; TRAVIS, A.J. et al. 16S rDNA library-based analysis of ruminal bacterial diversity. Antonie van Leeuwenhoek, v. 86, p.263-281, 2004.

EDWARDS, J.E.; KINGSTON-SMITH, A.H.; JIMENEZ, H.R. et al. Dynamics of initial colonization of nonconserved perennial ryegrass by anaerobic fungi in the bovine rumen. FEMS Microbial Ecology, v.63, p.141-142, 2008.

FERRER, M.; GOLYYSHINA, O.V.; CHERNIKOVA, T.N. et al. Novel hydrolase diversity retrieved from a metagenome library of bovine rumen microflora. Environmental Microbiology, v.7, p.1996-2010, 2005.

FERRER, M.; BELOQUI, A.; GOLYYSHINA, O.V. et al. Biochemical and structural features of a novel cyclodextrinase from cow rumen metagenome. Biotechnology Journal, v.2, p.207-213, 2007.

GREGG K.; COOPER, C.L.; SCHAFER, D.J. et al. Detoxification of the plant toxin fluoroacetate by a genetically modified rumen bacterium. BioTechnology, v.12, p.1361-1365, 1994.

GREGG, K.; HAMDORF, B.; HENDERSON, K. et al. Genetically modified ruminal bacteria protect sheep from fluoroacetate poisoning. Applied and Environmental Microbiology, v.64, p.3496-3498, 1998.

GUO, Y.Q.; LIU, J.X.; LU, Y. et al. Effect of tea saponin on methanogenesis, microbial community structure and expression of mcrA gene, in cultures of rumen microorganisms. Letters in Applied Microbiology, v.47, p.399-404, 2008.

HANDLESMAN, J. Metagenomics: application of genomics to uncultured microorganisms. Microbiology and Molecular Biology Reviews, v.68, p.669-685, 2004.

JANSSEN, P.H.; KIRS, M. Structure of the archaeal community of the rumen. Applied and Environmental Microbiology, v.74, p. 3619-3625, 2008.

JOBLIN, K.N. Ruminal acetogens and their potential to lower ruminant methane emissions. Australian Journal of Agricultural Research, v.50, p.1307-1313, 1999.

KANG, S.; DENMAN, S.E.; MORRISON, M. et al. An efficient RNA extraction method for the estimation of gut microbial diversity by PCR. Current Microbiology (in press), 2009.

KAWASAKI, H.; MIYOSHI, K.; TONOMURA, K. Purification, crystallization and properties of haloacetate halidohydrolase from Pseudomonas species. Agricultural and Biological Chemistry, v.45, p.543-544, 1981.

KIM, B.R.; SUIDAN, M.T.; WALLINGTON, T.J. et al. Biodegradability of trifluoroacetic acid. Environmental Engineering Science, v.17, n.6, p.337-342, 2000.

KRAUSE, D.O.; W. J. SMITH, W.J.; MCSWEENEY, C.S. Extraction of microbial DNA from rumen contents containing plant tannins. Biotechniques, v.31, p.294-298, 2001.

KRAUSE, D.O.; DENMAN, S.E.; MACKIE, R.I. et al. Plant cell wall degradation in the rumen: microbiology, ecology, and genomics. FEMS Microbiology Reviews, v.27, p.663-693, 2003.

KRAUSE, D.O.; SMITH, W.J.M.; BROOKER, J.D. et al. Tolerance mechanisms of streptococci to hydrolysable and condensed tannins. Animal Feed Science and Technology, v.121, p.59$75,2005$.

KUNIN, V.; COPELAND, A.; LAPIDUS, A. et al. A bioinformatician's guide to metagenomics. Microbiology and Molecular Biology Reviews, v.72, p.557-578, 2008.

LARUE, R.; YU, Z.; PARISI, V.A. et al. Novel microbial diversity adherent to plant biomass in the herbivore gastrointestinal tract, 
as revealed by ribosomal intergenic spacer analysis and rrs gene sequencing. Environmental Microbiology, v.7, p.530-543, 2004.

LEAPHART, A.B.; LOVELL, C.R. Recovery and analysis of formyltetrahydrofolate synthetase gene sequences from natural populations of acetogenic bacteria. Applied and Environmental Microbiology, v.67, p.1392-1395, 2001.

LEAPHART, A.B.; FRIEZ, M.J.; LOVELL, C.R. Formyltetrahydrofolate synthetase sequences from salt marsh plant roots reveal a diversity of acetogenic bacteria and other bacterial functional groups. Applied and Environmental Microbiology, v.69, p.693-696, 2003

MACKIE, R.I.; CANN, I.K.O.; ZOETENDAL, E.G. et al. Molecular approaches to study bacterial diversity and function in the intestinal tract. In: INTERNATIONAL SYMPOSIUM ON THE NUTRITION OF HERBIVORES, 7., 2007, Bejing. Proceedings... Beijing: China Agricultural University Press, 2007. p.75-107.

MAKKAR, H.; MCSWEENEY, C.S. Methods in gut microbial ecology for ruminants. Springer, The Netherlands, 2005. p. 225 .

MARGULIES, M., EGHOLM, M., ALTMAN, W.E. et al. Genome sequencing in microfabricated high-density picolitre reactors. Nature, v.437, p.376-380, 2005.

MCCOSKER, T. Ruminal detoxification of fluoroacetate. Agricultural Science (New. Series), v.2, p.46-47, 1989.

MCSWEENEY, C.S.; DENMAN, S.E.; WRIGHT, A.-D.G. et al. Application of recent DNA/RNA-based techniques in rumen ecology. AAAP Conference, Korea. Asian-Australasian Journal of Animal Science, v.20, p.283-294, 2006.

PADMANABHA, J.; GREGG, K.; FORD, M. et al. Protection of cattle from fluoroacetate poisoning by genetically modified ruminal bacteria. Animal Production Australian, v.25, p.293, 2004.

PALMER, C.; BIKE, E.M.;EISEN, M.B. et al. Rapid quantitative profiling of complex microbial populations. Nucleic Acids Research, v.34, p.5, 2006.

MOSONI, P.; CHAUCHEYRAS-DURAND, F.; BÉRA-MAILLET, C. et al. Quantification by real-time PCR of cellulolytic bacteria in the rumen of sheep after supplementation of a forage diet with readily fermentable carbohydrates: effect of a yeast additive. Journal of Applied Microbiology, v.103, P.26762685, 2007.

NICHOLSON, M.J.; KIM, E.J.; THEODOROU, M.K. et al. Understanding the molecular ecology of rumen fungi-A DDGE approach. In: WALLACE, R.J. (Ed.) 'Beyond Antimicrobials- the Future of Gut Microbiology' Proceedings of the 3rd RRI-INRA, Aberdeen, 2002.

ORPIN, C.G.; JOBLIN, K.N. The rumen anaerobic fungi. In HOBSON, P.N.; STEWART, C.S. (Eds.) The rumen microbial ecosystem. 2.ed. London: Blackie, 1997. p.140-195.

OUWERKERK, D.; KLIEVE, A.V.; FORSTER, R.J. Enumeration of Megasphaera elsdenii in rumen contents by real-time Taq nuclease assay. Journal of Applied Microbiology, v.92, p.753$758,2002$.

QI, M.; NELSON, K.E.; DAUGHERTY, S.C. et al. Novel molecular features of the fibrolytic intestinal bacterium Fibrobacter intestinalis not shared with Fibrobacter succinogenes as determined by suppressive subtractive hybridization. Journal of Bacteriology, v.187, p.3739-3751, 2005.

RIMOUR, S.; HILL, D.; MILITON, C. et al. GoArrays: highly dynamic and efficient microarray probe design. Bioimformatics, v.21, p.1094-1103, 2005.

SALZMAN, N.H.; JONG, H.D.; PATERSON, Y., et al. Analysis of $16 \mathrm{~S}$ libraries of mouse gastrointestinal microflora reveals a large new group of mouse intestinal bacteria. Microbiology, v.148, p.3651-3660, 2002.

SESSITSCH, A.; GYAMFI, S.; STRALIS-PAVESE, N. et al. RNA isolation from soil for bacterial community and functional analysis: evaluation of different extraction and soil conservation protocols. Journal of Microbiological Methods, v.51, p.171$179,2002$.

SOKOL, H.; LEPAGE, P.; SEKSIK, P. et al. Temperature gradient gel electrophoresis of fecal $16 \mathrm{~S}$ rRNA reveals active Escherichia coli in the microbiota of patients with ulcerative colitis. Journal of Clinical Microbiology, v.44, p.3172-3177, 2006.

STEVENSON, D.M.; WEIMER, P.J. Dominance of Prevotella and low abundance of classical ruminal bacterial species in the bovine rumen revealed by relative quantification real-time PCR. Applied Microbiology and Biotechnology, v.75, p.165-174, 2007.

STEWART, C.S.; FLINT, H.J.; BRYANT, M.P. The rumen bacteria, In: HOBSON, P.N., STEWART, C.S. (Eds.) The rumen microbial ecosystem. 2.ed. New York: Blackie Academic and Professionals, 1998. p.10-72.

SUNDSET, M.A.; EDWARDS, J.E.; CHENG, Y.F. et al. Molecular diversity of the rumen microbiome of Norwegian reindeer on natural summer pasture. Microbial Ecology (in press), 2008.

TAJIMA, K.; AMINOV, R.I.; NAGAMINE, T. et al. Diet-dependent shifts in the bacterial population of the rumen revealed with real-time PCR. Applied and Environmental Microbiology, v.67, p.2766-2774, 2001.

WAGNER, R. The regulation of ribosomal RNA synthesis and bacterial cell growth. Archives in Microbiology, v.161, p.100109, 1994.

WANG, R.F.; BEGGS, M. L.; ERICSON, B. D. et al. DNA microarray analysis of predominant human intestinal bacteria in fecal samples. Molecular and Cellular Probes, v.18, p.223-234, 2004.

WANG, R-F.; BEGGS, M.L.; ROBERTSON, L.H. et al. Design and evaluation of ologonucleotide-microarray method for the detection of human intestinal bacteria in fecal samples. FEMS Microbiology Letters, v.213, p.175-182, 2002.

WEIMER, P.J.; STEVENSON, D.M.; MERTENS, D.R. et al. Effect of monensin feeding and withdrawal on populations of individual bacterial species in the rumen of lactating dairy cows fed highstarch rations. Applied Microbiology and Biotechnology, v.80, p.135-145, 2008 .

WHITE, B.A.; CANN, I.K.O.;KOCHERGINSKAYA, S.A. et al. Molecular analysis of archaea, bacteria and eucarya communities in the rumen: Review. Asian-Australasian Journal of Animal Science, v.12, p.129-138, 1999.

WILliAMS, A.G.; COLEMAN, G.S. The rumen protozoa, In: HOBSON, P.N.; STEWART, C.S. (Eds.) The rumen microbial ecosystem. New York: Blackie Academy Professional, 1998. p.73-139.

WRIGHT, A-D.; AUCKLAND, C.H.; LYNN, D.H. Molecular diversity of methanogens in feedlot cattle from Ontario and Prince Edward Island, Canada. Applied and Environmental Microbiology, v.73, p.4206-4210, 2007.

WRIGHT, A-D.; MA, X., OBISPO, N.E. Methanobrevibacter phylotypes are the dominant methanogens in sheep from Venezuela. Microbial Ecology, v.56, p.390-394, 2008.

YU, Z., MORRISON, M. Improved extraction of PCR-quality community DNA from digesta and fecal samples. Biotechniques, v.36, p.808-812, 2004a.

YU, Z., MORRISON, M. Comparisons of different hypervariable regions of rrs genes for use in fingerprinting of microbial communities by PCR-denaturing gradient gel electrophoresis. Applied and Environmental Microbiology, v.70, p.48004806, 2004b.

YU, Z.; FORSTER, R.J. PCR-based methods for analysis of populations and gene expression. 3.1 Nucleic acid extraction, oligonucleotide probes and PCR methods. In: MAKKAR, H.; McSWEENEY, C.S. (Eds.) Methods in gut microbial ecology for ruminants. Springer, The Netherlands, 2005.

YU, Z.; GARCÍA GONZÁLEZ, R.; MORRISON, M. Evaluations of different hypervariable regions of archaeal rrs in profiling of 
methanogens by Archaea specific PCR and denaturing gradient gel electrophoresis. Applied and Environmental Microbiology, v.74, p.889-893, 2008.

ZOETENDAL, E.G.; AKKERMANS, A.D.; DE VOS, W.M. Temperature gradient gel electrophoresis of 16S rRNA from human fecal samples reveals stable and host-specific communities of active bacteria. Applied and Environmental Microbiology, v.64, p.3854-3859, 1998.

ZOETENDAL, E.G.; KOIKE, S.; MACKIE, R.I. A critical view on molecular ecology of the gastrointestinal tract. In: MANNETJE, L. (Ed.) Matching herbivore nutrition to ecosystem biodiversity. Merida, Mexico, 2003. p.9-78.
ZOETENDAL, E.G.; COLLIER, C.T.; KOIKE, S. et al. Molecular ecological analysis of the gastrointestinal microbiota: A review. Journal of Nutrition, v.134, p.465-472, 2004.

ZOETENDAL, E.G.; RAJILIC-STOJANOVIC, M.; DE VOS, W.M. High-throughput diversity and functionality analysis of the gastrointestinal tract microbiota. Gut, v.57, p.1605-1615, 2008.

ZHU, Y.X.; WANG, J.Q.; MA, R.L. et al. Construction and analysis of rumen bacterial artificial chromosome library from a dairy cow rumen microflora. Acta Microbiologica Sinica, v.47, p.213-217, 2007. 